\title{
Laconian ßoũ $\alpha$ 'Band of Boys' as a Collective Noun
}

\author{
Elwira Kaczyńska \\ (University of Łódź)
}

\begin{abstract}

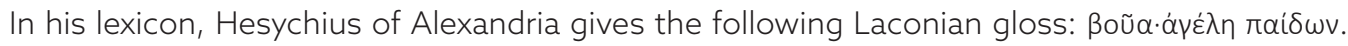
$<\wedge \alpha ́ k \omega v \varepsilon \varsigma>$ ("boũa: a band of young boys. Laconians"). This term is confirmed by epigraphical

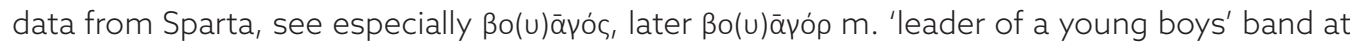
Sparta' (IG V.1.257; 283; 292; etc.). The author explains the registered lemma from etymological and morphological points of view, accepting A. J. van Windekens's etymology according to which the Laconian term ßoũ $\mathrm{f}$. is related to the Lithuanian gauja f. 'flock, pack, herd, bunch, band, gang'. She reconstructs the Indo-European nomen collectivum * gúúniā f. 'herd, pack, band', originally 'herd of cows, cattle' $(\leftarrow \mathrm{IE}$. " "goúus f./m. 'cow'), adding other reflexes taken from Latin and Indo-Aryan and Balto-Slavic languages, e.g. Latv. gauja f. 'crowd'; Skt. (Pāṇini) gávyā f. coll. 'cow-herd'; Vedic gávyam, gavyám n. coll. 'herd of cows'; Oriya gāba 'cattle', also 'a cow'; and so on.
\end{abstract}

\section{Keywords}

Ancient Greek; animals; collectives; etymology; Laconian dialect 


\section{Introduction}

Hesychius of Alexandria wrote a lexicon of literary, rare or dialectal words before the end of the fifth century AD. He registered many Old Laconian and Late Laconian terms. Three of them are connected with the Spartan education of young boys:

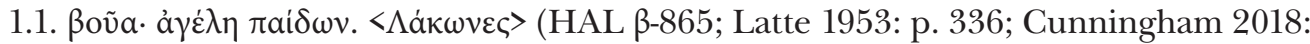
p. 453) "boũa: a band of boys. Laconians".

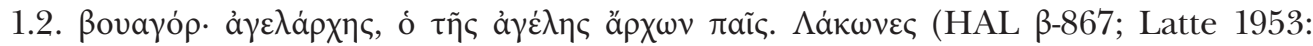
p. 336; Cunningham 2018: p. 453) "bouagór: leader of a flock or herd; boy-leader of a band of boys. Laconians".

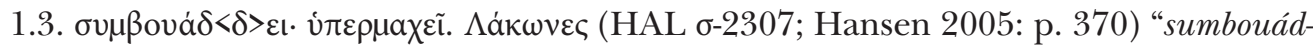
$d e i$ : [he] fights on behalf of [his boũa]. Laconians". ${ }^{1}$

It is obvious that these lemmas are related to each other. The term ßovajó $\rho$ represents a Late Laconian form, demonstrating the rhotacism of $-\varsigma$ in the final position (Lazzeroni 2006: p. 85). ${ }^{2}$ The agent noun in question has also been attested many times in some epi-

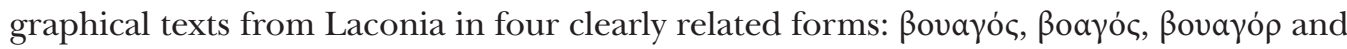
ßoаүó $\rho$ (IG V.1.257.1; 283; 292.6; 294.1; 305.6; 307.4; 312.4; 523; see Mitchell 1984: pp. 131, 133; Adrados 1994: p. 736; Liddell \& Scott 1996: p. 323; Montanari 2003: p. 415).

Below I quote one of the Spartan inscriptions of the second century AD (IG V.1.307; Schwyzer 1923: p. 34; Buck 1955: p. 271; Pisani 1973: p. 103; Bartoněk 2015: pp. 134135):

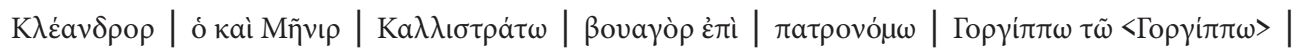

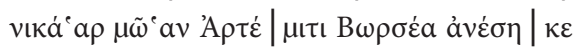

“Kleandros, called also Menis, Kallistratos' son, leader of young boys' band, offered for Artemis Ortheia, having won in singing (in a musical conquest) in the time of performing office of patronomos by Gorgippos, the son of Gorgippos" (my own translation; cf. Kaczyńska 2014: p. 66$).^{3}$

1 Many dictionaries (e.g. Frisk 1960: p. 255; Chantraine 1968: p. 188; Liddell \& Scott 1996: p. 1677) record

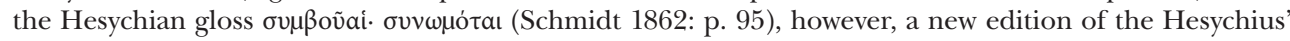

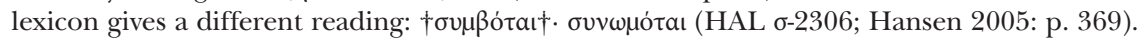

2 Numerous Laconian glosses, registered in the lexicon by Hesychius of Alexandria (5th c. AD), demonstrate

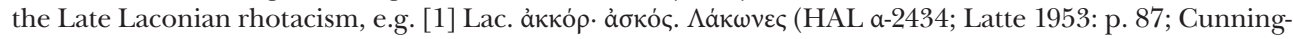
ham 2018: p. 115), cf. Gk. Hom. ảokó $\Lambda a ́ \kappa \omega v \varepsilon \varsigma$ (HAL $\beta-645$; Latte 1953: p. 328; Cunningham 2018: p. 442) < Gk. Doric *Fí $\sigma \omega \varsigma$, cf. Gk. Attic

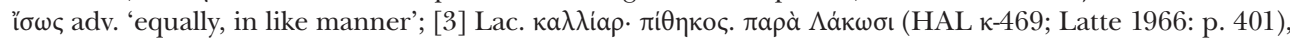

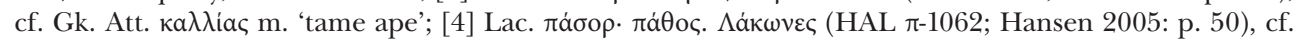

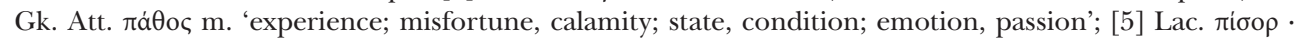

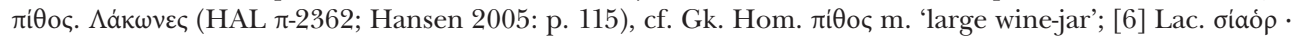

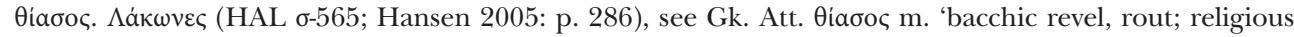

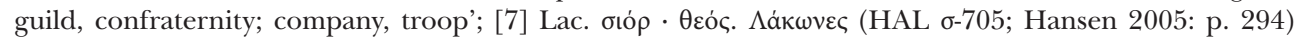

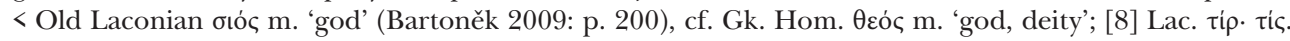

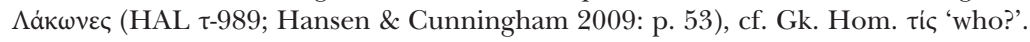

3 The English translation given by Antonín Bartoněk (2015: p. 135, No. 103) runs as follows: "Kleandros and Menis, son of Kallistratos, the commander of the band of boys under the leadership of Gorgippos, son of Gorgippos, a victor in singing ["in Muse"], dedicated to Artemis Orthia". 


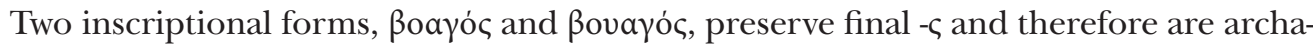

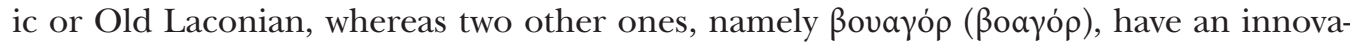
tive character and belong to the Late Laconian dialect. From the morphological point of view the Laconian appellative $\beta o(v) \bar{\alpha} \gamma o ́ \varsigma$, Late Laconian $\beta o(v) \bar{a} \gamma o$ o m. 'leader of a band of boys in Sparta' represents a compound formation, containing the specific (probably local) appellative ßoṽa f. 'band of boys' (attested only in the Hesychian lexicon) in the first part and the agent noun àyó $\mathrm{m}$. 'leader, chief' (Liddell \& Scott 1996: p. 14; Montanari 2003: p. 62) in the second one.

In my article I would like to explain the origin and etymology of the mysterious Laconian term ßoṽa $\mathrm{f}$. 'band of the Spartan boys', synonymic to the well known Ancient Greek appellative å $\gamma \varepsilon \dot{\lambda} \eta$, Doric ả $\gamma \dot{\varepsilon} \lambda \bar{\alpha}$ f. 'herd, flock (of horses, cows, pigs or birds); shoal (of fish)', also 'a band in which boys were trained (in Crete and Sparta)' (Willetts 1969: p. 162; Davaras 1989: p. 2; Link 1994: p. 23).

\section{An overview of existing explanations of Lac. ßoũ $\alpha$ f. 'band of boys'}

Four different etymologies have been proposed for the Laconian term in question so far. I present them below in the chronological order.

The first explanation was proposed by Bernhard Laum (1924: p. 11), who assumed that the term Laconian ßoṽa, denoting a kind of the competition for the Spartan boys,

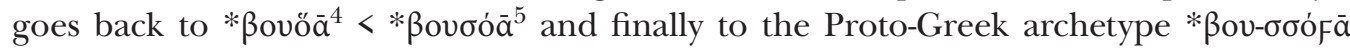
f. 'driving away cattle', cf. Gk. oєúw 'to hunt, chase; drive away; hurry away' (Liddell \& Scott 1996: pp. 1591-1592) < IE. * * $k^{u}$ ieu- 'sich in Bewegung setzen’ (Pokorny 1959: p. 539; Rix 2001: pp. 394-395). ${ }^{6}$ This derivation was regarded earlier as impossible by Friedrich Bechtel (1923: pp. 368-369), as the geminate - $\sigma \sigma$ - cannot be lost in Laconian. Accepting Laum's etymology, Paula Wahrmann reaches an alternative conclusion that Lac. ßoṽa may represent "ein Hyperarchaismus" (see Kretschmer \& Wahrmann \& Kroll \& Vetter 1929: p. 242). Pierre Chantraine connects the Laconian term in question with Gk. ßoũ 'cow', but following Bechtel's position he ignores Laum's explanation. Finally he says as follows: "Un rapport avec ßoṽ s est plausible, mais par quelle derivation?" (Chantraine 1968: p. 188). Also Beekes rejects this explanation on the basis of a phonological premise ("original $\sigma \sigma$ would not have disappeared [in Laconian]").

The second etymology was suggested by Albrecht von Blumenthal (1930: p. 9). In his

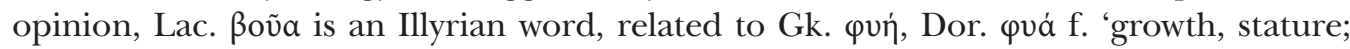

4 The term ßovöa 'a group of young people' in the Etymologicum Magnum (208.6; 391.19G) represents a corrected form by Hemsterhuis, cf. Adrados (1994: p. 746, s.v. ßovбóā). According to Mitchell (1984: p. 132),

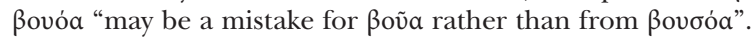

5 An artificial form ßovøóā f. 'flock, herd, children's group in Sparta / grey, agrupación infantil en Esparta', created on a wrong etymology, is introduced to the fourth volume of Diccionario griego-español (Adrados 1994: p. 746, s.v.).

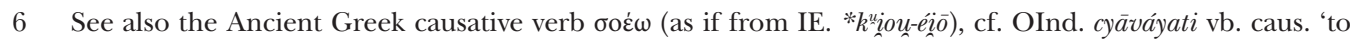
cause to move, shake, agitate' (Monier-Williams 1999: p. 403). 
substance', also 'prime of age'. This etymology is commonly rejected by linguists for semantic reasons, cf. "semantisch unbefriedigend" (Frisk 1960: p. 255); "hypothèse en l'air qui ne va pas pour le sens" (Chantraine 1968: p. 188); "This is semantically improbable" (Beekes 2010: p. 229).

According to Arthur James Beattie, Lac. ßoṽa f. 'band of boys' is related to Gk. ßoń f.

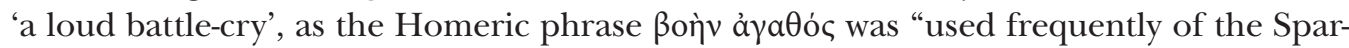
tan Menelaus in the Iliad (II 408 etc.)” (Mitchell 1984: p. 132, quotes Beattie's opinion as a personal communication). The third explanation is nothing more than a guess.

The fourth etymology, not mentioned in Beekes' dictionary, was suggested by Albert Joris van Windekens (1986: p. 48), who following Chantraine in connecting Lac. ßoṽa with Gk. ßoṽ s proved that the above-mentioned connexion is indirect ("rapport n'est qu'indirect"). In his opinion, the Late Laconian term ßoṽ $\mathrm{f}$. 'band of boys' is closely related to Lithuanian gaujà f. 'flock, pack, herd, bunch, band, gang' and goes back to an Indo-European protoform derived from IE. * $g^{u} \bar{o} u s \mathrm{~m} . / \mathrm{f}$. 'cow' with the original meaning 'herd, horde / troupeau, horde'. ${ }^{7}$ He correctly stresses that the suggested relationship is perfect from the semantic point of view ("La concordance sémantique est complete"; Windekens 1986: p. 48).

Our short overview of existing explanations of Lac. $\beta$ oṽ clearly demonstrates that the three former etymologies should be rejected for semantic, phonological or formal reasons, whereas the fourth explanation, though probably requires some additional comments, seems highly plausible.

\section{A new interpretation of Lac. $\beta$ oṽ $\alpha$ as a nomen collectivum}

None of the researchers have noticed that the Ancient Greek word ßoṽa f. 'band of boys', attested in the Laconian dialect, may represent a collective form. The comparison of the Laconian word in question with Lith. gaujà f. 'flock, pack, herd, bunch, band, gang' allows to put a new hypothesis, according to which both terms are reflexes of an IndoEuropean collective noun, derived from the oblique root ${ }^{*} g^{u}$ ou - (nom. sg. $\left.{ }^{*} g^{u}{ }^{u} \underline{u} u s\right) \mathrm{m} . / \mathrm{f}$. 'cow' by means of the "collective" suffix * $*_{-} \bar{a}\left(<\right.$ PIE. $\left.{ }_{-i} i e h_{2}\right)$. There are many instances demonstrating a high productivity of this suffix in the Indo-European languages, including Ancient Greek, e.g.

3.1. Gk. Att. $\varphi \rho \bar{a} \tau \rho i \bar{a}$, dial. (in Chios and Tenos) $\varphi \bar{a} \tau \rho i \bar{\alpha}$ f. coll. 'brotherhood; people of kindred race, tribe, clan' (Liddell \& Scott 1996: p. 1953); Lith. brotìa f. 'circle of the most faithful friends' (with the progressive dissimilation of $r-r>r-\emptyset$ ); Old Slovenian bratria, Old Serbian bratrja, Old Russian бpampua f. coll. 'brotherhood', Old Polish bratrza f. coll. 'brotherhood, brothers' (< Proto-Slavic *bratrija f. coll. 'brotherhood'); Toch. A pratri

7 The Indo-European archetype * $g^{u} \overline{0}$ unira , which van Windekens reconstructs, cannot be accepted. Such a protoform could only represent a dual form, cf. Gk. Hom. ő $\sigma \sigma \varepsilon$ du. 'two eyes' < PIE. * $h_{3} e k^{u} \underline{i} \partial_{1}$ 'id.', cf. Lith. aki du. 'two eyes', Pol. oczy pl. 'eyes' (<PSl. *oč $i$ du. 'two eyes'). The dual form is completely doubtful in the case of a collective name with the meaning 'herd of cows, cattle'. 
'brothers' < IE. *bhrātriyā f. coll. 'brotherhood' (Pokorny 1959: p. 164; Witczak 2016: pp. 126-130) < PIE. * ${ }^{h} r e h_{2}-t r-i e h_{2}$ (Derksen 2008: p. 60; Matasović 2014: p. 145).

Accepting the proposed derivation of Lac. ßoṽ a f. 'band of boys' from IE. * $g^{u} 0 u$ ' cow' (as suggested by P. Chantraine and A. J. van Windekens) we should reconstruct the IndoEuropean collective noun * $g^{u}$ oui $i \bar{a}$ f. 'herd, pack, band', originally 'a herd of cows, cattle'. Moreover, we are able to indicate some further reflexes of the original collective formation. Firstly, the Lithuanian word gaujà f. (4 AP) 'flock, pack, herd, bunch, band, gang / troupeau, horde' has a close equivalent in Latvian gauja f. 'crowd, a lot of (people); multitude' (Fraenkel 1962: p. 140; Derksen 2015: p. 166). Wojciech Smoczyński derives the East Baltic appellatives in questions from the verbal root *gau- 'to obtain, receive' attested in Baltic: Lith. gáuti 'to receive, obtain', Latv. gaût 'to catch, try to obtain, receive', OPrus. pogaūt 'to receive' (Smoczyński 2007: p. 164). Rick Derksen quotes two different derivations of Lith. gaujà: the first follows Smoczyński's explanation, the second treats Latv. gauja as a "cognate with the word for 'cow' ( $\rightarrow$ Latv. gùous)" (Derksen 2015: p. 116). In my opinion, the latter etymology is semantically better founded than the former one. Why? The East Baltic forms cannot be separated from the Sanskrit collective noun gávyā f. 'a cow-herd' (Monier-Williams 1999: p. 351), which is registered by Pāninini's work (IV $2.50)$.

I am convinced that the Baltic words, as well as the Laconian term ßoṽa and OInd. gávya , go back to the Indo-European protoform * $g^{u}$ ou ${ }^{u} \bar{a}$ f., which represents a collective noun (nomen collectivum) with the original meaning 'cattle, herd of cows' and is etymologically motivated by the Indo-European nominal root * $g^{u \prime} o u$ - f./m. 'cow'. The Baltic and Greek languages demonstrate the following semantic change: 'herd of cows, cattle' (an original meaning attested in Sanskrit) > 'flock, herd' (in Lithuanian) > 'pack or crowd of animals' (in Lithuanian only) > 'crowd of people, band, gang' (in both East Baltic languages) > 'band of young boys' (in Laconian). The above-mentioned development may be additionally confirmed by the Modern Greek material. It cannot be excluded that the intermediate meaning 'crowd of people' (registered both in Latvian and Lithuanian) appears to be preserved in the name of Bova (Gk. Boṽa), denoting the "Zentrum der griechischen Dörfer in Kalabrien” (Rohlfs 1964: p. 91). If the suggested connection is correct, then my hypothesis on the collective character of the Greek, Sanskrit and Baltic forms finds additional confirmation.

It is worth emphasizing that Sanskrit gávyā f. 'a cow-herd' is not an isolated formation in Indo-Aryan. The collective noun gávyam (also gavyám) n. 'cattle, herd of cows' has been attested in some hymns of RigVeda (RV I 140.13; V 34.8; VII 18.7; IX 62.23) (Monier-Williams 1999: p. 351), as well as in modern Indo-Aryan languages, e.g. Oriya gāba 'cattle', also 'a cow' as the effect of a singularization of the old collective form (Turner 1966: p. 219). Collective formations (of neuter gender) ending with *-iom seem to be parallel to these in *-ia (of feminine gender), as it is demonstrated by two cognate formations, well attested in the Indo-European protolanguage: *bhrātriā f. coll. 'brotherhood' and *bhrātriom n. coll. 'id.'.

3.2. The latter archetype is reflected by OInd. bhrātryam n. 'brotherhood, fraternity' (Monier-Williams 1999: p. 770); Russ. dial. братъё -тъя n. coll., BRus. бра́трия n., Ukr. 
брámms n. 'brotherhood, brothers' (< PSl. East. *bratıje n. coll. 'brotherhood', earlier *bratrbje) and perhaps even by Toch. A pratri 'brothers' (Witczak 2016: p. 129).

The lexical data, mentioned earlier (see 3.1), clearly demonstrate that the former archetype is firmly attested in Greek, Baltic, Slavic (and probably in Tocharian). In other words, the Indo-Aryan forms for 'cattle, herd of cows' (e.g. OInd. gávyam, gavyám n., Oriya $g \bar{a} b a$ ) are evidently related to the feminines (with a collective meaning), attested in Greek (Lac. ßoṽa), Indo-Aryan (Skt. gávyā) and Baltic (Lith. gaujà, Latv. gauja).

\section{The phonetic development of IE. *gứựīa to Lac. ßoũ $\alpha$}

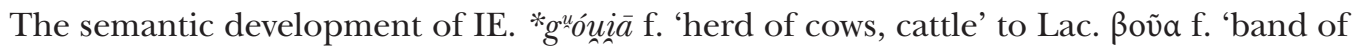
boys' is explained in section 3. Here I discuss the phonetic development of IE. * $g^{u}{ }^{u}$ ui ${ }_{n} \bar{a}$ in Ancient Greek.

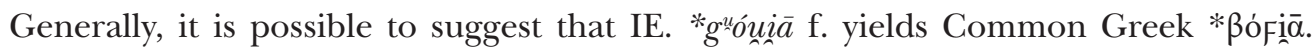
The internal digamma ${ }_{F}$ is lost in most Ancient Greek dialects, including Laconian, e.g.

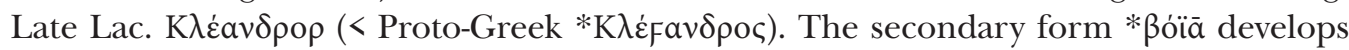
regularly to Doric Greek ßoiā and further to $\beta$ óā in the Laconian dialect, cf. Late Lac.

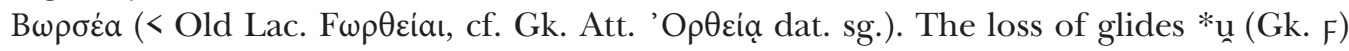
and $*_{\mathrm{i}}(\mathrm{Gk} . \mathrm{\iota})$ in the internal (especially intervocalic) position is perfectly attested in Laconian (Mitchell 1984: pp. 658, 710).

In my opinion, the development of $\beta$ óa to Late Laconian $\beta$ oṽa completely agrees with the common change of $\mathrm{o}>\mathrm{ov}$ in numerous Modern Greek dialects. The long vowel $\omega$ [॰:], which alternates with ov in Late Laconian (Lazzeroni 2006: pp. 86-87), is usually rendered as ov $[\mathrm{u}]$ in Tsakonian, the modern continuation of the Laconian dialect of Ancient Greek (Liosis 2014: p. 447), e.g. Tsak. $\gamma \rho o u ́ \sigma \alpha$ f. 'tongue' < Lac. $\gamma \lambda \tilde{\omega} \sigma \sigma \alpha$ f. 'id.'; Tsak.

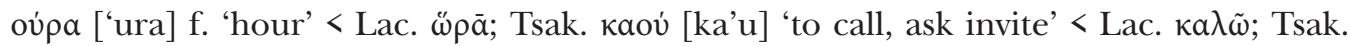

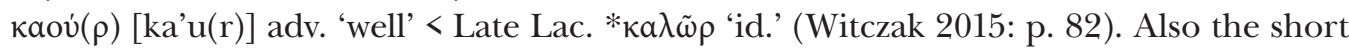
vowel $\mathrm{o}[\mathrm{o}]$ in the neighbourhood of a labial stop commonly gives ov [u] in Tsakonian,

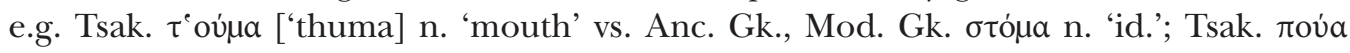

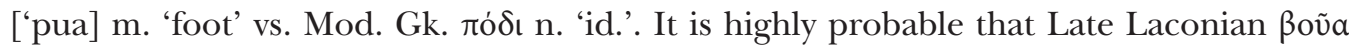
represents an earlier form $\beta$ óā. It is worth emphasizing that the Laconian inscriptions demonstrate not only Late Laconian ßovāyó (or ßovāyós), but also an earlier variant ßō̄jós.

\section{Remarks on the accentuation of Lac. $\beta$ oũ $\alpha$}

Some researchers suggest that the circumflex attested in the Hesychian lemma ßoṽa is false. It is a common opinion expressed by two authors of etymological dictionaries of the Ancient Greek language, cf. "l'accentuation doit être fautive" (Chantraine 1968: p. 188; Windekens 1986: p. 48 repeats the same phrase). In fact, the Greek language lost a differentiation between the long and short vowels as early as in the first century 
BC. Generally, the Ancient Greek accent has been preserved until today, but both its melodic character and the primitive distinction between the circumflex, the acute and the grave were completely lost two thousands years ago. Of course, Greek grammarians of the late ancient times, like e.g. Hesychius of Alexandria, apply the traditional rules of the classical accentuation. The final - $\alpha$ after phonemes other than $\varepsilon[\varepsilon], \mathrm{l}[\mathrm{i}], \rho[\mathrm{r}]$ in the Attic dialect, as well as in the Hellenistic koiné, was always treated as a short vowel. It is obvious that the Greek grammarians recorded dialectal words according to the standard principles. This is why the circumflex in the Late Laconian gloss can be questioned. However, the place of accent in the initial syllable is relatively certain. The barytone accent is also attested in Pāninin's work (IV 2.50: gávyā f. 'a cow-herd'). In other words, there is a completed accentual and formal agreement between Lac. ßoṽa and Skt. gávyā (both go back to IE. * $g^{u}$ oui $\bar{a}$ f.). However, the attested Lithuanian stress (the $4^{\text {th }}$ accentual paradigm in the literary language) seems to indicate an alternative variant with the oxytonic stress (as if from IE. * g góui ${ }^{u} \bar{a}$ f.). Is it possible to suggest two oppositional accents for the same collective noun?

It cannot be excluded that the observed accentual differentiation is caused by a crossing between two alternative types of accentuation of the Indo-European collectives. The situation in RigVeda seems similar. The Old Indic collective noun gavyam n. 'herd of cows' demonstrates not only the barytone stress: gávyam (RV I 140.13; V 34.8; IX 62.23), but also the oxytone one: gavyám (once in RV VII 18.7), as recorded by Monier-Williams (1999: p. 351). It should be noted that the feminine collective noun *bhrátria seems to demonstrate a barytone accent (cf. the lexical data recorded in 3.1), ${ }^{8}$ whereas the cognate neuter formation *bhrātrióm (3.2) appears to have an oxytone stress, cf. also OInd. (RV) bhrātrám n. coll. 'brotherhood, fraternity' (Monier-Williams 1999: p. 770). This is why it is possible to put a tentative hypothesis that the Indo-European feminine collective derived from IE. * $g^{\prime \prime}$ 'ou- 'cow' was stressed initially (i.e. IE. * $g^{u}$ ó $u i \bar{a}$ f. coll.), whereas the cognate neuter collective finally (i.e. IE. * ${ }^{*}{ }^{n}$ ó uióm n. coll.). Of course, this situation might lead to creating forms with a secondary accentuation, e.g. Vedic gavyám turns into gávyam under the influence of Skt. gávyā f. coll. 'a cow-herd'. If my explanation is correct, then the $4^{\text {th }}$ accentual paradigm in Lithuanian must be treated as a secondary phenomenon.

\section{Slavic and Latin-Romance reflexes of the collective noun *g"oujīa}

Above I demonstrated that the feminine noun ${ }^{*} g^{u}$ ou ${ }_{n} i \bar{a}$ is attested in three Indo-European subgroups: Baltic, Greek and Indo-Aryan. In these subgroups a collective meaning was generally preserved. Note, however, that the Oriya term gāba demonstrates not only a collective meaning ('cattle'), but also a singulative one ('a cow') (Turner 1966: p. 219). Below I would like to discuss further possible cognates that completely have lost their original collective sense.

8 It should be emphasized, however, that most Greek collectives demonstrate an oxytone stress (Schwyzer 1939: p. 469). 
The South Slavic languages demonstrate two cognate forms, which, in my opinion, remain in an etymological relation to Lac. ßoṽa, namely Serbo-Croatian gúja f. 'snake, viper', dial. (western) 'ascarid, Ascaris lumbricoides L.', dial. also 'epilepsy', Bulgarian (dial.) гул 'viper'. The Slavic terms seem to derive from Proto-Slavic *guja f. 'snake, viper' (Trubačev 1980: p. 168). The Proto-Slavic archetype may be treated as a primitive nomen collectivum with the original meaning 'a crowd of snakes (or vipers)'. The Proto-Slavic origin of the Serbo-Croatian and Bulgarian forms, as well their possible relationship to the East Baltic forms, is sometimes questioned by the reason of narrow geographical range and a different meaning (so Slawski 2001: pp. 299-300). In fact, the local distribution of the South Slavic equivalents theoretically may indicate a substratum borrowing (perhaps from an Illyrian or Dalmatian *gaujā).

It is not impossible that Latin bŏva, also b̆a f. 'snake, especially water snake' and a number of Italo-Romance forms, e.g. Italian dial. (Piemontese) boa 'worm, caterpillar / Wurm, Raupe', (Val Sessia) bova 'id.', (Mailandish) boa 'fog stripes / Nebelstreifen', perhaps also a diminutive form bovolo 'snail / Schnecke' (Meyer-Lübke 1935: p. 110, s.v. bŏva "Schlange"), derive from the Indo-European collective name * $g^{u}$ ouia $\mathrm{f}$. as well, cf. a similar development in Lat. ŏvum n. 'egg' (< IE. *ōuióm n. 'egg', cf. Gk. ழ̣óv n. ‘id.’). Of course, the Latin term bŏva f. cannot be treated as an inherited term by the reason of the initial phoneme $b$-. However, the development of ${ }^{*} g^{u}$ - to $b$ - is typical of Osco-Umbrian, as well as Celtic. Many animal names (both wild and domesticated ones), attested in the Latin vocabulary, were probably borrowed from the Osco-Umbrian languages, especially from the Sabinic one, e.g. Lat. bōs, bŏvis m. f. 'cow' $(\leftarrow$ as if from Sabinic *bous < IE. * $g^{u}$ ous); Lat. bufō f. 'toad' (< IE. * $g^{u} 0 u d h \bar{o} n$, cf. OInd. gōdh $\overline{\bar{a}}$-, also gōdhik $\bar{a}$ - f. 'a kind of lizard, iguana'); Lat. burdō or burdus m. 'hybrid of a stallion and a female donkey, hinny' (< IE. * $g^{u}$ ordhōn or * $g^{u}$ ordhos, cf. OInd. gardabhá- m. 'donkey, ass', Toch. B kercapo 'ass, donkey'); Lat. lupus m. 'wolf' (< IE. *luk"os m. 'id.' by a Sabinic mediation); Lat. ursus m.

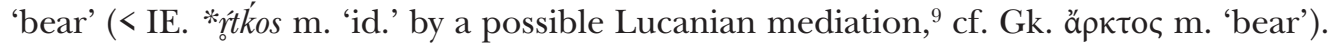

The striking connection of the South Slavic and Latino-Romance forms seems to demonstrate a special semantic development from 'herd of cows' (in Indo-European) > 'pack of wild animals' > 'crowd or bundle of snakes' and further (as a result of a supposed singularization) to 'a snake' (in Latin and South Slavic) and 'a viper, a worm, a caterpillar, an ascarid' (in Italo-Romance and South Slavic).

\section{Conclusions}

In my paper I have analysed the Laconian term ßoṽa f. 'band of boys' from the viewpoint of the Indo-European etymology and word-formation. The detailed and careful investigations presented above lead to the following results:

1. Having presented four different explanations for Lac. ßoṽa suggested so far, I reached the conclusion that Albert Joris van Windekens (1986: p. 48) gave a correct

9 Cf. Varro's words (Ling. 5.100): ursi Lucana origo, vel, unde illi, nostri ab ipsius voce; see also Maltby (1991: p. 656). 
etymology of the Laconian word, comparing it with Lith. gaujà f. 'flock, pack, herd, bunch, band, gang'.

2. Close equivalents are to be found not only in Lithuanian, but also in Latvian gauja f. 'crowd, a lot of (people); multitude' and Sanskrit gávyā f. 'a cow-herd'. It cannot be excluded that Latin $b o(v) a$ f. '(water) snake', SC. gúja f. 'snake, viper', Bulg. dial. zýя 'viper' are related as well.

3. The comparison of the Laconian term ßoṽa $\mathrm{f}$. 'band of boys' with its possible equivalents, attested in Balto-Slavic, Indo-Aryan and Italic languages, strongly suggests

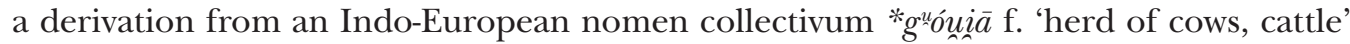
$\left(\leftarrow\right.$ IE. * $g^{u} \cdot \bar{\prime} u s$ f./m. 'cow'), see especially Sanskrit gávyā f. coll. 'a cow-herd'.

\section{Bibliography}

Adrados, F. R. (1994). Diccionario griego-español (Vol. IV). Madrid: Consejo Superior de Investigaciones Científicas.

Bartoněk, A. (2009). Dialekty klasické rěctiny. Brno: Masarykova univerzita.

Bartoněk, A. (2015). Chrestomathy of Ancient Greek Dialect Inscriptions. München: Lincom.

Bechtel, F. (1923). Die griechischen Dialekte, II: Die westgriechischen Dialekte. Berlin: Weidmannsche Buchhandlung.

Beekes, R. (2010). Etymological Dictionary of Greek. Leiden - Boston: Brill.

Blumenthal, A. von (1930). Hesychstudien. Untersuchungen zur Vorgeschichte der griechischen Sprache nebst lexikographischen Beiträgen. Stuttgart: W. Kohlhammer.

Buck, C. D. (1955). The Greek Dialects. Grammar, Selected Inscriptions, Glossary. Chicago: The University of Chicago Press.

Chantraine, P. (1968). Dictionnaire étymologique de la langue grecque. Histoire des mots. (Vol. I). Paris: Klincksieck.

Colvin, S. (2007). A Historical Greek Reader. Mycenaean to the Koiné. Oxford: Oxford University Press. Cunningham, I. C. (2018). Hesychii Alexandrini Lexicon, I: A- $\Delta$. Berlin - Boston: De Gruyter.

Davaras, C. (1989). Guide to Cretan Antiquities. Athens: Eptalofos.

Derksen, R. (2008). Etymological Dictionary of the Slavic Inherited Lexicon. Leiden - Boston: Brill.

Derksen, R. (2015). Etymological Dictionary of the Baltic Inherited Lexicon. Leiden - Boston: Brill.

Fraenkel, E. (1962). Litauisches etymologisches Wörterbuch (Vol. I). Heidelberg: Carl Winter.

Frisk, Hj. (1960). Griechisches etymologisches Wörterbuch (Vol. I). Heidelberg: Carl Winter.

Hansen, P. A. (2005). Hesychii Alexandrini Lexicon, III: $\Pi-\Sigma$. Berlin - New York: Walter de Gruyter.

Hansen, P. A., \& Cunningham, I. C. (2009). Hesychii Alexandrini Lexicon, IV: T- $\Omega$. Berlin - New York: Walter de Gruyter.

Kaczyńska, E. (2014). W sprawie genezy psł. *dik๘ 'dziki' [On the Origin of Proto-Slavic *dikz 'wild']. In M. Jakubowicz, \& B. Raszewska-Żurek (Eds.), Studia Borysiana. Etymologica - Diachronica - Slavica. W 75. rocznice urodzin Profesora Wiestawa Borysia (pp. 63-71). Warszawa: Instytut Slawistyki PAN.

Kretschmer, P., Wahrmann, P., Kroll, W., \& Vetter, E. (1929). Literaturbericht für das Jahr 1926. Glotta, 17(3-4), 191-305. 
Latte, K. (1953). Hesychii Alexandrini Lexicon, I: A- . Hauniae: Ejnar Munksgaard.

Latte, K. (1966). Hesychii Alexandrini Lexicon, II: E-O. Hauniae: Ejnar Munksgaard.

Laum, B. (1924). Das Eisengeld der Spartaner (Verzeichnis der Vorlesungen an der Akademie zu Braunsberg). Königsberg: Hartung.

Lazzeroni, R. (2006). Il dialetto di Sparta fra cedimento e restaurazione. Incontri Linguistici, 29, 83-90.

Liddell, H. G., \& Scott, R. (1996). A Greek-English Lexicon. Oxford: Clarendon Press.

Link, S. (1994). Das griechische Kreta. Untersuchungen zu seiner staatlichen und gesellschaftlichen Entwicklung vom 6. bis zum 4. Jahrhundert v. Chr. Stuttgart: Franz Steiner Verlag.

Liosis, N. (2014). Tsakonian. In G. K. Giannakis (Ed.), Encyclopedia of Ancient Greek Language and Linguistics (Vol. III; pp. 446-450). Leiden - Boston: Brill.

Maltby, R. (1991). A Lexicon of Ancient Latin Etymologies. Leeds: Francis Cairns.

Matasović, R. (2014). Slavic Nominal Word-Formation. Proto-Indo-European Origins and Historical Development. Heidelberg: Universitätsverlag Winter.

Meyer-Lübke, W. (1935). Romanisches etymologisches Wörterbuch (3th ed.). Heidelberg: Winter.

Mitchell, E. A. (1984). The Laconian Dialect (Thesis submitted for the degree of Doctor of Philosophy). Edinburgh: University of Edinburgh.

Monier-Williams, M. (1999). A Sanskrit-English Dictionary. Delhi: Motilal Banarsidass Publishers.

Montanari, F. (2003). Vocabolario della lingua greca. Torino: Loescher.

Morani, M. (1999). Introduzione alla linguistica greca. Il greco tra le lingue indeuropee. Alessandria: Edizioni dell'Orso.

Pisani, V. (1973). Manuale storico della lingua greca. Brescia: Paideia Editrice.

Pokorny, J. (1959). Indogermanisches etymologisches Wörterbuch. Bern - München: Francke.

Rix, H. (Ed.). (2001). Lexikon der indogermanischen Verben. Die Wurzeln und ihre Primärstammbildungen. Wiesbaden: Dr Ludwig Reichert Verlag.

Rohlfs, G. (1964). Lexicon Graecanicum Italiae Inferioris. Etymologisches Wörterbuch der unteritalienischen Gräzitat. Tübingen: Max Niemeyer Verlag.

Schmidt, M. (1862). Hesychii Alexandrini Lexicon (Vol. IV, Pars I). Ienae: Fredericus Maukius.

Schwyzer, E. (1923). Dialectorum Graecarum exempla epigraphica potiora. Lipsiae: Salomon Hirzel.

Schwyzer, E. (1939). Griechische Grammatik (Vol. I). München: C. H. Beck'sche Verlagsbuchhandlung.

Sławski, F. (Ed.). (2001). Stownik prastowianski [Proto-Slavic dictionary] (Vol. VIII). Wrocław - Warszawa - Kraków: Zakład Narodowy im. Ossolińskich, Wydawnictwo PAN.

Smoczyński, W. (2007). Stownik etymologiczny jezyka litewskiego [Etymological dictionary of the Lithuanian language]. Wilno: Uniwersytet Wileński.

Trubačev, O. N. (1980). Этимологический словарь славянских языков. Праславянский лексический фонд(Vol. VII). Москва: "Наука".

Turner, R. L. (1966). A Comparative Dictionary of the Indo-Aryan Languages. London: Oxford University Press.

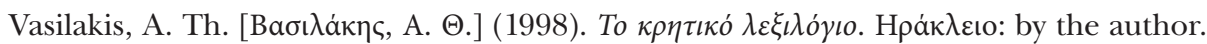

Willetts, R. F. (1969). Everyday Life in Ancient Crete. London - New York: B. T. Batsford; G. P. Putnam's Sons.

Windekens, A. J. van (1986). Dictionnaire étymologique complémentaire de la langue grecque. Leuven: Peeters. 
Witczak, K. T. (2015). On the Chronology of the Loss of * $\lambda$ in Tsakonian (Late Laconian). GraecoLatina Brunensia, 20(2), 177-188.

Witczak, K. T. (2016). Nierozpoznane collectivum w językach tocharskich: toch. A pratri 'bracia' [An Unrecognized Collective Noun in the Tocharian Languages: Toch. A pratri 'brothers']. Roczniki Humanistyczne, 64(9), 119-133.

Dr Hab. Elwira Kaczyńska prof. nadzw. UŁ / elwira.kaczynska@uni.lodz.pl

Chair of Classical Philology

University of Łódź, Faculty of Philology

Pomorska 171/173, 90-236 Łódź, Poland 
